\title{
The State's Responsibility in Fulfilling Domestic Energy Needs
}

\author{
Burhanuddin * Abrar Saleng ${ }^{2}$ Juajir Sumardi ${ }^{2}$, \\ Abd. Maasba Magassing ${ }^{3}$ \\ 1.PhD Students at Postgraduate Program, Faculty of Law, Hasanuddin University \\ 2. Professor on Legal Science, Faculty of Law, Hasanuddin University \\ 3.Associate Professor on Legal Science, Faculty of Law, Hasanuddin University
}

\begin{abstract}
After the proclamation of independence in 1945, the management of electrical energy began with the establishment of the Electricity and Natural Gas Bureau by the government on October 27, 1945. Electrical energy is a source of life for a nation that affects overall development. Therefore, electricity is categorized as a basic need that is the livelihood of many people. In the context of state responsibility to fullfill the domestic energy need, Indonesia has responsibility to provide energy as the domestic needs in the forms of as a provider. In fulfilling domestic electricity needs, the state in its position as a provider can be seen from the existence of electricity policies that are oriented towards efforts to provide electricity in sufficient, equitable and quality quantities. It has responsibility also to provide energy as the domestic needs in the forms of as a regulator. In terms of it, the fulfilment of the domestic energy needs can be found in some laws such as the Law No. 30 of 2007 on the Energy, the Law No. 30 of 2009 on Electricity, the Law Number 21 of 2014 concerning Geothermal Energy, The Government Regulation Number 79 of 2014 concerning National Energy Policy, and the Government Regulation Number 7 of 2017 concerning Geothermal For Indirect Use. Another responsibility of the state is a state as an entrepreneur. It is placed in the Chapter XIV on the title of the National Economy and Social Welfare Article 33. Finally, the last state responsibility of providing domestic energy needs is a state as an umpire.
\end{abstract}

Keywords: State Responsibility, Domestic Energy Needs

DOI: $10.7176 / J L P G / 81-03$

\section{Introduction}

The beginning of human life is marked by its interaction with nature. The nature provides various needs for human life to be managed and utilized for the survival of humans themselves. In the development of management and its use to meet the needs of human life, it causes various problems in terms of availability. One form of natural use in question is through management to make it an energy resource as vital for human life.

The history of energy management in Indonesia has been dated back to the Dutch colonial government in 1897. Energy management in the electricity sector was carried out for the first time by the Dutch East Indies Electric Company named Nederleandche Indische Electriciteit Maatschappij (NIEM). ${ }^{1}$ At that time, NIEM used the Ciliwung River for steam power generation (PLTU). In 1909, NIEM expanded to Surabaya by establishing a gas company called Nederleandche Indische Gas Maatschappij (NIGM). In the same year, NIGM established a subsidiary called Algemeene Nederleandche Indische Electriciteit Maatschappij (ANIEM) as a private company that was given the right to build and manage electricity systems and in a short time became the largest private electricity company in Indonesia which controlled $40 \%$ of domestic electricity needs. ${ }^{2}$

After the proclamation of independence in 1945, the management of electrical energy began with the establishment of the Electricity and Natural Gas Bureau by the government on October 27, 1945. The agency was established to avoid electricity being a source of chaos even though it faced problems other than the unclear ownership status of the generation. also the problem of the limited resources that are capable of reorganizing and managing the generation that has been severely damaged since the Japanese occupation mastered. ${ }^{3}$ The spirit of independence made the determination to manage independently of electricity and natural gas as sources that controlled the lives of many people.

As a new state at that time, Indonesia with its independence had the determination to take over management of natural resources where after a long time in the grip of colonial rule. It was time for sovereignty to be enforced in all aspects of national and state life especially in terms of economic sovereignty, sovereignty of resource management -energy sources. ${ }^{4}$

Electrical energy is a source of life for a nation that affects overall development. Therefore, electricity is categorized as a basic need that is the livelihood of many people. The discussion of the relationship between the

\footnotetext{
${ }^{1}$ See http://engineering08.blogspot.com/2015/06/sejarah-adanya-listrik-di-indonesia_87.html accessed August 24, 2018.

2 ibid

${ }^{3}$ See Purnawan Basundoro. http: // basundoro. blog .unair.ac.id / 2009/01/31 / from-electricity-colonial-to-listrik-national-studi-awal-tentangnv-aniem-surabaya / accessed on August 24, 2018.

${ }^{4}$ Juajir Sumardi, Academic Movement for Indonesian Oil and Gas Sovereignty, Makassar: Arus Timur, 2017, p. 19.
} 
State and citizens in principle is inseparable from a relationship of responsibility. In the Constitution of the Republic of Indonesia, it is affirmed that the State is responsible for citizens. The responsibility of this country covers the fields of education, social welfare, health and security. ${ }^{1}$

The responsibility of the state was born as a consequence of the life of the nation which was organized in the form of a republic, which implies a mandate in order topubli $c$ welfare can be realized. One of its manifestations is the obligation of the State to serve citizens in order to fulfill their basic needs. ${ }^{2}$ The republic system adopted by Indonesia places the people as the highest holders of sovereignty. According to Mac Iver, each modern country, sovereignty is shown through the will of the people as the last holder of power and because of the highest power possessed, he is able to create power and from there also determines responsibility. ${ }^{3}$ It is said to create power because the will of the people is the only source of power for every government. ${ }^{4}$

In relation to the teachings of Jean Jack Rousseau, it is stated that there are 2 (two) kinds of people's will, namely 1). The will of the whole people (Volunte de Tous ).This people's will is used only once, when the State is formed through "community agreement" or "social contract". 2). The will of the majority of the people ( Volunte Generale ). This will is declared after the establishment of the State, and this becomes the basis for making decisions based on a majority vote. ${ }^{5}$

\section{The State's Responsibility in Fulfilling Domestic Energy Needs}

The presence of the state in guaranteeing the availability of electricity is constitutional responsibility as confirmed in Article 33 paragraph (2) and paragraph (3) of the 1945 Constitution of the Republic of Indonesia. Those paragraphs states that natural wealth is controlled by the state to be utilized for the greatest prosperity of the people. The constitutional responsibility of the state in the utilization of energy sources is directed at meeting the domestic energy needs for the achievement of people's prosperity. This constitutional responsibility is found in the elaboration of the functions of the state in fulfilling domestic energy.

\subsection{Responsibilities of State as a Provider Energy Needs}

In the Indonesian translation, the word Provider is interpreted as a provider, which if converted into a verb means to provide, provide, hold, determine, give. ${ }^{6}$ The state responsibility as a provider in this matter is how the state guarantees that the energy resources managed are still available and can benefit the greatest prosperity of the people. When the energy sources are owned as natural resources contained within the earth can be managed optimally and sustainably, then energy (electricity) can be available in order to fulfill the energy needs of the people. So, the responsibility of the state is here in terms of how the state meets the needs of its citizens with efforts to organize, provide and even provide.

The function of the state as a provider can be seen from the actions of the State to bring prosperity through meeting energy needs. This is in line with the conception of the welfare state where the State functions as a welfare tool. ${ }^{7}$ According to Friedman, the function of the provider is related to the concept of the welfare state. In this capacity, the state is responsible for providing social services to guarantee minimum living standards and provide leeway or freedom of economic forces. ${ }^{8}$ If examined more deeply, then in understanding the state provider functions as stated by Friedman, it can be seen in the relationship between the economy and social welfare. From here then set minimum standards of State service to its citizens in order to encourage the achievement of social welfare.

Understanding of the national economic system is related to state ownership rights amid a wave of economic liberalization and still many poor people. This indicates that economic development cannot necessarily advance public welfare and social justice for all Indonesians. This state control in relation to the national economy is the legal consideration of the Constitutional Court in the verdict of the decision of Law Number 20 of 2002 concerning Electricity. ${ }^{9}$

State responsibility cq. Government in the universal concept as stated by Ridwan HR, that the failure of the implementation of nachtwachtersstaat ${ }^{10}$ then the idea emerged to put the government as the party who is

\footnotetext{
${ }^{1}$ Jazim Hamidi and Mustafa Lutfi. Civic Education. Jakarta: Gramedia Pustaka. 2010. p. 100.

${ }^{2}$ Luthfi J. Kurniawan and Mustafa Luthfi, Regarding State, Law \& Public Policy, Malang: Setara Press, 2012 , p. 138.

${ }^{3}$ Mac Iver, Modern Country, translated by Moertono. $2^{\text {nd }}$ ed., Jakarta: Aksara Baru, 1988. p. 183.

${ }^{4}$ I Dewa Gde Atmadja, Ilmu Negara, Malang: Setara Press. 2012. p. 87.

${ }^{5}$ Ibid.

${ }^{6}$ See www.babla.co.id Indonesian translation.

${ }^{7}$ See Jimlly Asshiddiqie, Constitution of the State, Malang: Setara Press, 2015, p. 299.

${ }^{8}$ See FX. Joko Priyono. Summary the State and the Rule of Law in A Mixed Economy, in W. Friedman, Semarang: Faculty. Law of Diponegoro University, 2002.

${ }^{9}$ Jimlly Asshiddiqie, op.cit, p.301.

${ }^{10}$ Nachtwachtersstaat is also called the Night Guard State, where the State is limited to taking care of the economic life of the community. The state becomes passive and only keeps security and order. As an antithesis, the concept of Walfare State was born, known as the concept of the State of Welfare.
} 
responsible for the welfare of its people. This idea is known as universalism. The main characteristic of this country is the emergence of government obligations to realize public welfare for its citizens. According to Ridwan H.R., welfare state is a concrete form of the principle shipt of staatsonthounding, which limits the role of the state and the government to interfere with the political life of society, economic and social society become staatsbemoeienis who want the state and government to be actively involved in the economic and social life of the community, as a step to realize public welfare. ${ }^{1}$

Mac Iver's further stipulates that in the context of a welfare state, the welfare state places the Ssate as a functioning body / government to provide minimum standards for the daily living conditions of citizens through political and economic control. From this, it can be concluded that the state functions as a welfare tool and as a tool of economic control as outlined in a state law. The Political and economic control are two different things but in principle they cannot be separated. The power to control is an authority born of the highest authority called popular sovereignty or democracy. However, the democracy that wants to be addressed is a complete democracy that is not only in politics but also in the economic field.

The political sovereignty is called political democracy, while economic sovereignty is called economic democracy. Both cannot be separated because according to Soekarno ${ }^{2}$ that the combination of political and economic democracy will result in social democracy which of course leads to the realization of the ideals of social welfare as ideas developed by the founding fathers as a whole and comprehensive democracy as reflected in the opening of the 1945 Constitution and in Chapter XIV concerning the National Economy and Social Welfare. ${ }^{3}$ In his speech, Mohammad Hatta stated that economic democracy does not require economic autocracy, as in political democracy it does not want political autocracy. The political democracy does not adequately represent sovereign people without being equipped with economic democracy, because without the economic democracy, there will be a concentration of economic power in one or several groups which will then form economic powers that can "buy" or "regulate" political power. ${ }^{4}$

The constitution is a guarantee of the economic concepts embraced by reason relating to how the state plays a role in realizing the ideals of prosperity. This can be seen from socio-economic activities which are previously considered as private activities, in which each person of the people beyond the reach of the state's functions. It is changed to become part of the scope of responsibility of the welfare state. ${ }^{5}$ The concept of a welfare state places the state to oblige and guarantee the creation of common prosperity in people's lives, both concerning economic, social, cultural, legal, educational and political interests. ${ }^{6}$ The state's obligation to bring prosperity is certainly based on the country's constitution. In Indonesia, the Constitution NRI 1945 as a constitution, put the well-being as one of the goals as a state as affirmation Preamble NRI 1945 paragraph 4 (four), "... to protect the entire Indonesian nation and the entire homeland of Indonesia, and to advance general welfare, to educate life of the nation, ..."

The meaning of general welfare is always related to the economy. The history records that after independence, economic conditions still have not been able to prosper the people. In addition to the consequences of the war, economic resources from strategic industrial sectors such as mining, banking and agriculture are still controlled by foreign businessmen. So that economic activities are still capital compared to economic activities dominated by indigenous entrepreneurs. This was what prompted the Soekarno government at that time to nationalize foreign companies from the Dutch. ${ }^{7}$

The dynamics of the regulation of social welfare in the 1945 Constitution can be seen from the initial changes in social welfare arrangements regulated in Chapter XIV entitled "Social Welfare". Aall articles on the economy must be read and understood in the conception of social welfare. Post the fourth amendment, Chapter XIV is entitled "National Economy and Social Welfare". Separated mention between economy and welfare should not be seen as two different concepts, both of which must be interpreted as a whole from social welfare to social justice. ${ }^{8}$ As a constitution oriented to social justice for all the people of Indonesia, in principle the understanding of social welfare must be placed within the framework of the national economy. Economic practice must be in the spirit of justice, because justice is the way to achieve the ideal of well-being. Thus, according to Jimly Asshiddiqie ${ }^{9}$, all constitutional directions concerning the national economy must be read in a welfare perspective, "welfare state", or according to Bung Hatta's term, the "management state".

The foundation of state power in carrying out the welfare function in the energy sector is the 1945

\footnotetext{
${ }^{1}$ Ridwan HR. State Administrative Law , Revised Edition. Jakarta: Rajawali Press. 2011. p. 14

${ }^{2}$ Ir. Soekarno is the first Indonesia President.

${ }^{3}$ JiImly Asshiddiqie. Indonesian Constitution \& Constitutionalism. $3^{\text {rd }}$ ed., Jakarta: Sinar Grafika. 2014. p. 124.

${ }^{4}$ Elli Ruslina. "The meaning of Article 33 of the 1945 Constitution in the Development of Indonesian Economic Law", Journal of the Constitution, Volume 9, Number 1, March 2012. p. 68.

${ }^{5}$ Jimly Asshiddiqie. Constitutional Law \& Pillars of Democracy. $3^{\text {rd }}$ ed., Jakarta: Sinar Grafika. 2015. p. 127.

${ }^{6}$ Lutfi J. Kurniawan \& Mustafa Lutfi. op.cit. p. 49.

${ }^{7}$ Jimly Asshiddiqie. Economic Constitution. $2^{\text {nd }}$ ed., Jakarta: Kompas Media Nusantara. 2016. p. 216.

${ }^{8}$ Jimly Asshiddiqie, Idea of a Social Constitution. $2^{\text {nd }}$ ed.,. Jakarta: LP3ES. 2015. p. 96

${ }^{9}$ Ibid, p.97.
} 
Constitution of the Republic of Indonesia especially in the fourth paragraph which emphasizes the direction and purpose of the state including advancing general welfare. It is also in Article 33 paragraph (2) and paragraph (3) of the 1945 Indonesian Constitution. Article 33 Paragraph (2) states that "production branches that are important to the state and which control the livelihood of many people are controlled by the State." Article 33 Paragraph (3) furthermore states that "Earth and Water and the natural wealth contained in them are controlled by the State and are used for the greatest prosperity of the people." Both paragraphs become the foundation and framework for each state policy / action cq. The government in terms of fulfilling energy (electricity) as a basic need for the people.

The electrical energy is a basic need for the people, including production which is important for the state and controls the livelihood of many people. These branches of production which are important to the state and which control the livelihoods of many people are the objects of state control in the form of organizing themselves or through the power of business to state enterprises as part of the function of State entrepreneurs. ${ }^{1}$ The meaning of state control relates to the principles of economic democracy adopted in the provisions of Article 33 of the 1945 Constitution of the Republic of Indonesia. In its explanation, it is said that economic democracy, production is done by all, for all under the leadership or ownership of community members. The prosperity of the community is prioritized not the prosperity of a person. Therefore, the economy is structured as a joint venture based on the principle of family. ${ }^{2}$

The orientation of state control is for prosperity. The principle of kinship is a proof that in principle the economic system as the ideals of the founding fathers of the economy is an economy that expressly rejects individualism and capitalism which basically requires the role of the State to be reduced. The principle of kinship does not only reject the liberal concept of the economy but also rejects the state's authority which is absolute and arbitrary in the form of ownership of production goods (system of etatism). The basic principle of economic values adopted is the principle of harmonization, namely the creation of harmony, balance and harmony. ${ }^{3}$

It is not only the branches of production, but also the earth, water, and natural resources contained in the earth are the main points of the people's prosperity so they must be controlled by the State. ${ }^{4}$ State control or the right to control the state is intended not as property rights as understood in the field of civil law. The state ownership rights include all natural resources or national natural resources, both those that have rights over them individually (directly controlled), or those that have no rights or not yet above them. All of these natural resources, without exception, are controlled by the State or become objects of State control. ${ }^{5}$

The scope of the understanding of state ownership rights can also be seen in the provisions of the Basic Agrarian Law (UUPA) wherein Article 2 paragraph (2) states as the authority of the state to:

a. Regulate and organize allotment, use, inventory and maintenance;

b. Determine and regulate the rights that can be owned by (part) of the earth, water and space;

c. Determine and regulate legal relations between people and legal actions regarding earth, water and space.

The power in question is about all earth, water and space. The word all implies the overall meaning both that has been abused by individuals and legal entities, or not. ${ }^{6}$

The concept of the right to control of the state (mastery) in Article 33 of the 1945 Constitution of the Republic of Indonesia does not mean ownership. The right to master is not to own. It is because mastery is more to processes, ways or actions to master something that contains the authority and ability to use and use it for survival. ${ }^{7}$ Unlike the case with the meaning in the concept of ownership where the emphasis lies in rights, not the object. As stated by Panesar that: " property, in legal terms, therefore means a right to thing rather than the things self", that is property rights in legal terms, means the right to something more than the goods themselves. ${ }^{8}$ From then known several concepts concerning the property rights, private property, common property and the

\footnotetext{
${ }^{1}$ In the decision of the Constitutional Court No.001-021-022 / PUU-I / 2003 concerning the testing of Law No. 20 of 2002 concerning Electricity against the 1945 Constitution of the Republic of Indonesia, in its consideration it is said that the branches of production which are objects of State control include: important for the State and controlling the lives of many people, important for the State but not affecting the lives of many people, and not important for the State but controls the livelihood of many people. Regarding the three scope of objects of this State control, the government together with the House of Representatives that assesses what and when a branch of production is said to be important for the State and controls the livelihood of many people. However, for the assessment, it was said that the Constitutional Court has the authority to test it against the 1945 Constitution of the Republic of Indonesia when there are parties who feel that their constitutional rights have been impaired.

${ }^{2}$ The explanation section contained in the original text of the 1945 Constitution before the amendment.

${ }^{3}$ Aminuddin Ilmar, The Right of State to Control in Privatization of the State-Owned Enterprises, Jakarta: Kencana, 2012 , p. 56.

${ }^{4}$ See the explanation in the original text of the 1945 Constitution.

${ }^{5}$ Syaiful Bakhri. Oil and gas for the People, Grafindo. Jakarta: Grafindo, 2013, p. 45.

${ }^{6}$ Farida Patittingi, Legal Dimensions of Small Islands in Indonesia. Yogyakarta: Rangkang Education. 2012 . p.91.

${ }^{7}$ Ibid, p.76.

${ }^{8}$ Ibid, p.77.
} 
state property. All three are more influenced by politics and personal. ${ }^{1}$

The space for debate over state ownership rights in principle is how to see the relationship between the state and natural resources. It is because the source of natural wealth is an important factor in economic development that determines the fulfillment of people's livelihoods. Abrar Saleng affirms that state ownership rights are not property rights (eigendoms), as in the field of civil law, but are within the scope of public law (publiekrechtelijk). ${ }^{2}$ The state ownership rights over natural resources can be linked to the domain principle, namely that any land that cannot be proven ownership is owned by the State. So that immovable objects within the state's authority both in ownership and control status are administratively determined based on the following matters: ${ }^{3}$

1. Its use is for the benefit of the community;

2. Due to its nature, it cannot be owned by individual humans;

3. Specifically determined for the state, because it is used by the state itself;

4. Due to its use gives public benefit, is controlled by the state; and

5. Determined by state law.

It is said furthermore that all natural resources are no exception, controlled by the state or become objects of state control rights. If there is still ownership rights over state ownership rights, it is because the state is not in the position of owner. So that in relation to the principle of the domain, in the mining sector, it can be seen that the relationship between State ownership and control over natural resources is because: ${ }^{4}$

1. $\quad$ its direct use by the state;

2. the control and use by the State will benefit the state's wealth and people's welfare, so it must be controlled by the state, even though it is a quai proposition (all or not absolute ownership / ownership);

3. it is the nation's national wealth, so that the state is seen as if it were the owner; and

4. Because the State operates a licensing system where the private sector can be given permission, to empower mining, so that the supervision and control is carried out by the government.

Different views on the meaning of "controlled by the state" in Article 33 of the 1945 Constitution of the Republic of Indonesia, for example, can be found in the Constitutional Court hearing on the request for testing of Law Number 20 of 2002 concerning Electricity. The Petitioner in this case argues that for the branch of electricity production, the meaning of "controlled by the state" must be interpreted as "owned by the state". Because if this is not the case, according to him, the supply of electricity, the price and utilization cannot be controlled properly and is guaranteed to be available in sufficient and equitable quantities, at prices that are affordable to people throughout Indonesia. ${ }^{5}$

It is so important that the meaning of state control over energy sources contained in natural wealth brings hope that the people's basic needs for electricity can be fulfilled. The state cq. the Government on a constitutional basis is obliged to provide and fulfill the basic needs of the people for electricity so that the control of the state is in the framework of achieving the greatest prosperity of the people. The Minister of State-owned Enterprises (BUMN) in his written statement at the trial of the electricity law states that the philosophy of mastery by the state was the creation of national security in the energy sector (oil and gas energy, electricity and other energy) in the NKRI with the main goal of supplying and distributing energy domestically. The government of any country is also obliged to provide and distribute energy throughout its territory. National resilience in the energy sector is the government's ability to manage energy, regardless of the size and richness of the State's poverty, nor does it regard whether a country has energy resources or not. ${ }^{6}$

The Constitutional Court of the Republic of Indonesia in its decision provides an interpretation of state control. The word "controlled by the state" must be interpreted in a broader sense that originates from and originates from the conception of the sovereignty of the Indonesian people over all "earth and water and the natural wealth contained therein", including in terms of ownership of people's collectivity, constructed by the 1945 Indonesian Constitution gave a mandate to the state to make a policy (regulation ) and management measures ( bestuursdaad), arrangements ( regelendeed), management ( beheersdeed ), and supervision ( toezichthoudensdaad $)^{7}$

In fulfilling domestic electricity needs, the state in its position as a provider can be seen from the existence of electricity policies that are oriented towards efforts to provide electricity in sufficient, equitable and quality

\footnotetext{
${ }^{1}$ Ibid.p.64.

${ }^{2}$ Abrar Saleng, Mining Law, Jogyakarta, UII Press, 2007. p. 210,

${ }^{3}$ Ibid.

${ }^{4}$ Ibid.pp.55-57.

${ }^{5}$ In the decision of the Constitutional Court Number: 001-021-022 / PUU-I / I / 2003. p. 259. The case in this decision is a material test of Law No. 22 of 2002 concerning the Electricity of the 1945 Constitution of the Republic of Indonesia.

${ }^{6}$ Written statement of the Minister of BUMN dated 29 July 2004, contained in the Constitutional Court decision Number: 001-021-022 / PUU-I / I / 2003. p. 242.

${ }^{7}$ See in the Constitutional Court decision Number: 001-021-022 / PUU-I / I / 2003. p. 334.
} 
quantities. In the general explanation section of Law Number 30 Year 2009 concerning Electricity, ${ }^{1}$ it is emphasized that the development of the electricity sector aims to advance the general welfare and intellectual life of the nation in order to realize national development goals, namely to create a just and prosperous society that is materially and spiritually based on 1945 Pancasila and the 1945 Constitution of the Republic of Indonesia. Electricity for the state in realizing public welfare in all fields, it is stated that the electricity supply business is controlled by the state and is used for the greatest prosperity of the people carried out by the government and regional government. The government and regional government are in accordance with their authority to establish policies, regulations, supervision and carry out electricity supply business. It is also emphasized that various electricity problems faced by the nation and the State have been anticipated in this Law. ${ }^{2}$

In addition, the affirmation of the functions of the state provider in fulfilling electricity needs can be seen from the efforts of electricity development where Article 2 paragraph (2) of Law No. 30 of 2009 concerning Electricity. It affirms that electricity development has the aim of ensuring the availability of electricity in sufficient quantities, good quality, and reasonable prices in improving the welfare and prosperity of the people in a fair and equitable manner and creating sustainable development. The electricity policy in principle can be seen from the general plan of national electricity. In the general provisions section, Article 1 paragraph (9) of Law Number 30 Year 2009 concerning Electricity (Electricity Law), the general plan for electricity is defined as a plan to develop an electricity supply system covering the generation, transmission and distribution of electricity needed to meet electricity needs. This general electricity plan is prepared based on national energy policies and is determined by the government after consultation with the House of Representatives of the Republic of Indonesia. ${ }^{3}$

National energy policy, which is a reference for the compilation of general electricity plans, is prepared as a guideline to give direction to national energy management to realize energy independence and national energy security to support sustainable national development. ${ }^{4}$ National energy policy is affirmed in Law Number 30 of 2007 concerning Energy (Energy Act), namely in Article 11 paragraph (2), and as an implementation of the provisions of Article 11 paragraph (2), a national energy policy has been drawn up which has been approved House of Representative of Indonesia Republic. National energy policy is stipulated in Government Regulation Number 79 of 2014 concerning National Energy Policy (PP 79/2014). The national energy policy based on PP 79/2014, stated in the provisions of Article 2, Article 3 and Article 4.

The availability of energy for domestic needs is a condition of energy availability to meet domestic needs. To present the availability of energy is certainly seen from the integrated stages as part of an energy management system that not only covers the provision itself but also the utilization and utilization. In the 2016 Indonesian Energy Outlook, an overview of the energy balance shows the equilibrium conditions between the energy supply side and the sectoral energy needs that cover production, conversion and transportation / distribution to end users. In the electricity sector, electricity supply is projected through the level of electricity production and generating capacity.

Electricity consumption in 2015 is $200 \mathrm{TWh}$. From this condition, along with population growth and economic growth, demand for electricity will continue to increase. Growth in electricity demand is projected to reach around $520 \mathrm{TWh}$ in 2025 and 2,200 TWh in 2050. The growth rate of electricity demand is an average of $7.1 \%$ per year during the $2015-2050$ period. ${ }^{5}$ Of the average $7.1 \%$ growth in electricity demand in the forecast period, the capacity for electricity production in total generating capacity is around $130 \mathrm{GW}$ in 2025 , and 460 GW of total plant capacity in $2050 .^{6}$

When compared with the data of the National Electricity General Plan (RUKN) for the period 2008-2027, where there is a difference in the amount of average growth in demand / demand for electricity that grows around $9.2 \%$ per year. The projected peak load of electricity needs in 2027 is estimated to reach $141.9 \mathrm{MW}$, while the projected electricity production in 2027 is in the range of $911.5 \mathrm{GWh}$. Thus the need for electric power needs to be prepared for additional generating capacity of at least $178.1 \mathrm{GW}$ until $2027 .^{7}$ By looking at the projections in Indonesia's Energy Outlook 2016, the State in its position as a provider, not only guarantees but also ensures that the availability of electricity is not a problem for national development. That the provision of

\footnotetext{
${ }^{1}$ The new Electricity Law after Law No. 20 of 2002 concerning Electricity is stated to have no binding legal force. Whereas Articles which are declared contrary to the 1945 Constitution of the Republic of Indonesia are the Articles which are considered as the heart of Law No. 20/2002 which regulates the problem of competition or business competition in management with an unbundling system , which includes generation, transmission and distribution which must be interpreted in an integrated manner (one unit) so as to avoid the emergence of chaos and uncertainty in its implementation, Law No. 20/2002 is declared contrary to the 1945 Constitution of the Republic of Indonesia and does not have binding legal force.

${ }^{2}$ See In the general explanation of Law No. 30/2009 Concerning Electricity.

${ }^{3}$ See Article 7 paragraph (1) of Law No. 30/2009 Concerning Electricity.

${ }^{4}$ See Article 5 of the Government Regulation of the Republic of Indonesia Number 79 of 2014 concerning National Energy Policy.

${ }^{5}$ See Indonesian Energy Outlook 2016. p. 96.

${ }^{6}$ Ibid.p.103.

${ }^{7}$ Decree of the Minister of Energy and Sumer Mineral Power Number 2682 K / 21 / MEM / 2008 concerning the 2008 National Electricity General Plan up to 2027.
} 
energy as part of energy management is directed at the utilization of available energy sources as Indonesia's natural wealth with the principle of justice and sustainability, for the presence of electricity in meeting equitable and affordable domestic needs for all Indonesian people.

\subsection{Responsibilities of the State as a Regulator}

The regulating function (regulator) of the state proposed by W. Friedmann. In principle, it relates to the function of the state provider. The conception of the welfare state is to provide space for "intervention" for the state towards the economic and social life of the community in order to realize the ideal of prosperity. ${ }^{1}$ The state intervention is found in its form as law. He also says that law is an instrument for modern countries to exercise control over the economic activities of society. ${ }^{2}$

In another perspective, Hans Kelsen actually stipulates the state as a legal system itself. In fact, every statement of its existence and its actions can only emerge as a legal action, as an act of creating or implementing legal norms. ${ }^{3}$ Hans Kelsen further assesses that the state as the subject of state law is none other than as a person, namely the personification of a system which is in its responsibility. Therefore according to Hans Kelsen, the problem of the state is a matter of responsibility. Every state action is only human action and the problem of responsibility is translated into the question why certain human actions are not the responsibility of the human being who acts itself but becomes the responsibility of the subject behind the human being. ${ }^{4}$

Hans Kelsen's assessment of the state as the subject of the law more than the role shown in his actions is a form of state responsibility carried out by officials in a structure stipulated by law. This means that when the state carries out its role through organs or more specifically the stakeholders of the organ (government instrument) whose authority is based on law / law. In principle, this is an elaboration of state responsibilities. The responsibility of the state in the form of regulating both laws and regulations made by government organs, In this case the ministry of energy and mineral resources, as the leading energy sector in electricity. Law in the sense is a law, which means as an instrument of the State in making arrangements. In this context, some matters that need to be regulated by law are: a) problems where the interests of many people are involved. The interests of many people need to be protected and regulated so that conflicts do not occur. b) problems that require certainty. Arrangements are needed to bring certainty because uncertainty can cause chaos. c). problems that will provide stability for change and community development. d). problems that will encourage various changes in society in an orderly and peaceful manner. ${ }^{5}$

The provision of electricity by the state is a constitutional obligation because it is the responsibility of the state to make arrangements. The electricity is the livelihood of many people. In the development of increasingly modern human life, electricity is the need of every person, every community group, every region, even national development needs. If it becomes the needs of many people, then arrangements are needed so that the state in managing energy resources can meet domestic electricity needs and everyone can obtain it in a peaceful and orderly manner.

In relation to the state's right to control energy resources, the constitutional court in its interpretation constructed people's collectivity in the 1945 Constitution of the Republic of Indonesia in which the state was given the mandate to regulate (regelendaad). This regulatory function is one of the 5 (five) aspects of the state's control of the earth and water and the natural wealth contained therein, as mentioned in the previous discussion. This state regulation function (regelendaad) is carried out through legislative authority by the House of Representatives (DPR) together with the government in the form of laws and regulations by the government in the form of Government Regulations or others. ${ }^{6}$

Based on the constitution as a framework for administering the state in carrying out its responsibility to fulfill domestic energy needs. Electricity in its arrangement is carried out through:

\section{a. The Law Number 30 of 2007 concerning Energy}

The regulation of fulfilling domestic electricity needs is an absolute matter for the state in its function as a regulator or regelendeed. As a basic people's need, energy has an important role to play in increasing economic activity and national security. Therefore, energy management which includes the provision, utilization and exploitation must be carried out in an equitable, sustainable, rational, optimal and integrated manner. ${ }^{7}$ Ensuring the availability of energy is the responsibility of the state so that through its regulatory function, energy

\footnotetext{
${ }^{1}$ See FX. Joko Priyono, Loc.cit.

${ }^{2}$ Ibid.

${ }^{3}$ Hans Kelsen, Introduction to Legal Theory. Translator, Siwi Purwandari. Print VIII. Bandung: Nusamedia. 2015. p. 150

${ }^{4}$ Ibid. p. 151 .

${ }^{5}$ Nukthoh Arfawie Kurde. Critical Analysis of the Law State Theory. $1^{\text {st }}$ ed.. Yogyakarta: Pustaka Pelajar. 2005 , p. 28.

${ }^{6}$ Although the DPR as the holder of power established a Law (Article 20 paragraph (1) of the 1945 Constitution of the Republic of Indonesia) but in paragraph 2, it was stated that each draft law was discussed together with the President for mutual agreement. However, in the case of submitting a draft law, the President can also submit a draft law (Article 5 paragraph (1). In addition to implementing the law, the president has the authority to stipulate a Government Regulation (Article 5 paragraph (2)).

${ }^{7}$ See the basis for consideration of Law No. 30 of 2007 concerning Energy.
} 
management must be carried out in an equitable, sustainable, rational, optimal and integrated manner. Legal arrangements in this matter, it wants to ensure that energy as natural resources can be enjoyed by all people equally, now and in the future.

In this law, energy regulation is contained in Chapter III which consists of 7 (seven) articles starting from Article 4 to Article 10. The seven articles include arrangements for energy resources, Energy buffer reserves, energy crisis and emergency conditions, energy prices, environment and safety, domestic content level, and international cooperation. The regulations concerning energy resources not only focused on fossil energy that cannot be renewed, but also new and renewable energy sources. This can be seen in Article 4:

1. Fossil energy, geothermal, large-scale hydro resources, and nuclear energy sources are controlled by the state and utilized for the greatest prosperity of the people.

2. New energy resources and renewable energy resources are regulated by the state and utilized for the greatest prosperity of the people.

3. The control and regulation of energy resources by the state, as referred to in paragraph (1) and paragraph (2), is carried out by the government in accordance with the provisions of the legislation.

The existence of non-renewable energy sources (fossil energy) as well as renewable ones is an object of state control and therefore arrangements have been made with the aim of being able to benefit the greatest prosperity of the people. Meanwhile, to meet national energy needs, the government is required to provide energy buffer reserves, ${ }^{1}$ in order to realize energy security. ${ }^{2}$

The condition of energy shortages (energy crisis) and the conditions in which energy supply is disrupted (energy emergency) is often a threat to meeting domestic energy needs. An increasingly modern life where the level of dependence on technology, however small it is depends on energy. So that if an energy crisis occurs, it will have implications for the disruption of the social life of the community both in the sector of economic activity and national development as a whole. In this condition, the function of the government would be disrupted in conducting public services. Therefore, prevention and countermeasures must be carried out by the government so that it does not become a problem that results in the disruption of national security. ${ }^{3}$ Provision of energy in order to meet people's needs for energy not only speaks of management activities, but also about the ability of people to buy. Therefore, the ability / purchasing power of the people is related to energy prices set by the government. Energy prices, as stated in Article 7, are determined based on fair economic value. In the explanation, the intended economic value is a value / cost that reflects the cost of energy production, including environmental costs and conservation costs and the benefits that are assessed based on the ability of the community and determined by the government. ${ }^{4}$

Energy supply is to fulfill energy needs. In the context of fulfillment, it does not only include availability but it is also affordability. Therefore, energy prices are an important thing for the state to regulate to ensure that all people without exception can enjoy energy. The economic price of energy should reflect the value of justice. The energy prices are determined not only by calculating the cost of production and how much the profit is, but what is equally important is how to calculate the level of ability / purchasing power of the people. Even if the government prepares subsidy funds for certain people or community groups, then in its implementation, it must be ensured right on target.

International cooperation can also be carried out to ensure national energy security, guarantee the availability of domestic energy and improve the national economy. This collaboration is carried out based on applicable laws and agreements that can have a broad and fundamental impact on the lives of the people must be with the approval of the DPR. ${ }^{5}$

\section{b. Law Number 30 of 2009 concerning Electricity}

This Law regulates everything related to electricity in terms of the supply, utilization and exploitation of electricity. Before the enactment of this law, 2 (two) laws were implemented, namely Law Number 15 of 1985 and Law Number 20 of 2002. In consideration of considering Law No. 30 of 2009, it is stated that electric power has a very important and strategic role in realizing national development goals. So, the electricity supply business is controlled by the state and its provision needs to be continuously improved in line with the development so that sufficient, equitable and quality electricity is available.

The Law Number 30 of 2009, in the general provisions explaining the purpose of an electricity supply business is the provision of electricity which includes the generation, transmission, distribution and sale of electricity to consumers. ${ }^{6}$ These four aspects of procurement constitute the scope of electricity supply for the

\footnotetext{
${ }^{1}$ Energy buffer reserves are the amount of available energy and energy sources stored nationally that are needed to meet national energy needs at a certain time. See article 5 .

${ }^{2}$ Energy security is a condition of ensuring the availability of energy and people's access to energy at affordable prices in the long term while paying attention to environmental protection.

${ }^{3}$ See article 6 The Law No. 30 of 2007.

${ }^{4}$ See article 7 The Law No. 30 of 2007 and its explanation.

${ }^{5}$ See article 10 The Law No. 30 of 2007.

${ }^{6}$ See Article 1 point 3 The Law No. 30 of 2009.
} 
public interest as stated in the provisions of Article 9 that the electricity supply business consists of electricity supply business for the public interest and electricity supply business for its own purposes. The difference between the two forms of business is the element of selling electricity which is not found in the electricity supply business for its own sake. ${ }^{1}$

Four aspects of electricity supply which consist of electricity generation, transmission, distribution and sales, in the provisions of Article 10 paragraph (2) are said to be carried out in an integrated manner. The phrase "can be done in an integrated manner" has been subjected to material testing of the 1945 Constitution of the Republic of Indonesia in the Indonesian Constitutional Court where the phrase is seen as not explicit in its regulation so that it can be interpreted as an activity that is not integrated or unbundling. The Court affirmed that the practice of Unbundling was not justified / contradicted to the 1945 Constitution of the Republic of Indonesia because the practice could eliminate state control. In the court ruling, it stipulates that Article 10 paragraph (2) is declared contrary to the 1945 Constitution of the Republic of Indonesia in a conditional manner and does not have binding legal force if the formulation in Article 10 paragraph (2) of Law No. 30 of 2009 concerning Electricity is interpreted as justifying the practice of unbundling in the business of providing electricity for public purposes. $^{2}$

The supply of electricity for the public interest is also related to the sale of electricity. Efforts to fulfill electricity needs as mentioned earlier are not only about their availability but also their affordability. The sale of electricity to the people / consumers is closely related to the selling price and electricity tariff. In its arrangement as stated in Article 33, where the selling price of electricity and rental of electricity networks are determined based on sound business principles.

There is no explanation of the principle of fair business referred to in Article 33 paragraph (1), so that in the decision of the Constitutional Court No. 111 / PUU-XIII / 2015 affirms that the phrase "fair business principle" does not lead to price setting based on market mechanisms as adopted by liberalism, because in paragraph (2) it is affirmed that the government or regional government based on its authority gives approval of the selling price of power electricity and electricity grid rental. It is reaffirmed in paragraph (3) where the holder of an electric power supply business license is prohibited from applying the selling price and rental of electricity without the approval of the government or regional government. With this arrangement, according to the court, it is the state that determines what and how the sound business principles are intended and on that basis the selling price of electricity and the price of renting the electricity network are stipulated.

The function of state regulation in this law can also be seen from the regulations relating to licensing. In this arrangement, a permit for an electricity supply business is stipulated by the government or regional government in accordance with its authority. ${ }^{3}$ There are 2 (two) types of business licenses to provide electricity, namely electricity supply business licenses and operating permits. Every person who organizes electricity supply for public interest must have an electricity supply business license. ${ }^{4}$

In carrying out the provisions of the electricity supply business license, the Government Regulation Number 14 of 2012 concerning Electricity Supply Business Activities as amended by Government Regulation Number 23 of 2014 concerning Amendments to the Government Regulation Number 14 of 2012 concerning Electricity Supply Business Activities is amended. Whereas the authority of the government or regional government in providing electricity supply business licenses is granted by the ministry, Governor, and Regent/Mayor. ${ }^{5}$

Granting licenses in phases in accordance with the authority given by the Law in principle is a form of control carried out by the government and local government through the creation of licensing governance by basing it on a decentralized system. There is a distribution of authority to the regions in order to ensure that every effort to provide electricity is a priority in energy development. Regional involvement is in the framework of giving space to regions to participate in the management of energy resources as natural resources that must be controlled and used for the greatest prosperity of the people.

With the issuance of permits through these authorities, the obligation arises for holders of electricity supply business licenses where Article 21 paragraph (1) PP No. 14 of 2012 states that "holders of electric power supply business licenses must provide continuous electricity that meets the standards of quality and reliability of electricity". The obligation for holders of electricity supply business licenses as confirmed in Article 21 becomes the basis for continuous electricity supply. Termination of provision can only be justified when: ${ }^{6}$

a. Required to carry out maintenance, expansion and rehabilitation work on electricity installations;

b. There is a disturbance in the electricity installation which was not due to negligence of the holders

\footnotetext{
${ }^{1}$ See Article 9 and 12 The Law No. 30 of 2009.

${ }^{2}$ See the Indonesian Constitutional Court No. 111/PUU-XIII/2015.

${ }^{3}$ See Article 21 The Law No. 30 of 2009.

${ }^{4}$ See Article 19 The Law No. 30 of 2009.

${ }^{5}$ Article 10 of the Government Regulation Number 14 of 2012 on Electricity Supply Business Activities.

${ }^{6}$ See Article 21 paragraph (2) PP No. 14 of 2012.
} 
of the electricity supply business license ${ }^{1}$

c. Situations that technically have the potential to endanger public safety occur; and / or $^{2}$

d. For the purposes of investigation in accordance with the provisions of legislation.

By looking at the four things as mentioned above where cessation of provision can be justified, there is no condition in the energy crisis. It means that the energy crisis is an unexpected condition. It can even be said to contradict the Law because electricity must be provided continuously.

\section{c. The Law Number 21 of 2014 concerning Geothermal Energy}

Geothermal is a renewable natural resource and is a natural wealth within the territory of the Unitary State of the Republic of Indonesia as a gift of Almighty GOD. As a renewable natural resource, geothermal has an important role in reducing dependence on fossil energy so that it becomes a foundation for efforts to maintain sustainability and national energy security in its use as a power plant, as stated in the basis of this Law.

In fulfilling domestic energy needs, geothermal energy is an alternative energy source to be exploited because in addition to its considerable potential for electricity generation, it is also a renewable energy that will not run out. This certainly will have a positive impact on the continuous supply of electricity. In this framework, the state in its function as regulator regulates the form of state control over energy resources. In this Law, the objectives of geothermal administration are confirmed article 3 and article 4.

The utilization of geothermal energy as stated in Article 3 is an effort to bring energy security and independence as a form of fulfilling domestic energy needs. Independence and energy security are very important for fulfilling energy needs because they are related to the utilization of energy resources potential to realize conditions where the availability of energy can be guaranteed and the community can enjoy it through affordable access from price aspects in the long term as well as environmental protection to maintain the sustainability of functions -function for human life and lead to the achievement of people's welfare and prosperity as the goal of state control over natural resources. The control of geothermal energy by the state is carried out by the government and regional governments based on their authority so that they can benefit the greatest prosperity of the people. ${ }^{3}$

In geothermal exploitation activities for their utilization, Article 9 regulates them by dividing 2 types of utilization, namely first, direct utilization used for; tourism, agribusiness, industry and other activities that use geothermal energy for direct use. Second, indirect use is used for electricity generation both for its own sake or for public interest. Whereas in Article 10, it is emphasized that geothermal energy for indirect use is a top priority in business. Geothermal exploitation is the main priority for electricity generation because so far electricity generation uses fossil fuels such as coal because it is considered relatively cheap and fairly large. However, these conditions lead to dependence on the non-renewable energy sector. There must be an effort to develop alternative energy and one of which is geothermal energy.

The presence of the state to regulate utilization through geothermal exploitation is certainly in order to control the exploitation activities for benefits of the people in meeting electricity needs. It is also to ensure that the sustainability of environmental functions can be maintained. Therefore, for each party or business entity wants to conduct geothermal exploitation for indirect use. It must first obtain a permit from the minister who organizes governmental affairs in the geothermal field. ${ }^{4}$

Geothermal exploitation whose working area is in a forest area must also include a permit to use or utilize the forest area from the minister who organizes government affairs in the forestry sector. ${ }^{5}$ Likewise for geothermal exploitation activities that are in the waters conservation area, it must have geothermal permits from the minister who organizes government affairs in the marine sector. ${ }^{6}$ Geothermal regulation is intended to present energy management through the use of renewable energy sources so that the supply of energy can continue as the people's need for energy increases and the potential for depletion of non-renewable energy sources diminishes.

\section{d. The Government Regulation Number 79 of 2014 concerning National Energy Policy}

This regulation relates to the direction of government policy in the energy sector. This government regulation was made to carry out the order of Law No. 30 of 2007 concerning Energy. Article 11 paragraph (2) of the Energy Law is affirmed that the national energy policy is determined by the government with the approval of the DPR. The requirement for DPR approval to determine energy policy is because it is related to the people's livelihood. The national energy policy in this government regulation is an energy management policy that

\footnotetext{
${ }^{1}$ In his explanation, what is meant by "not due to negligence" for example an electricity installation is subject to fallen trees or theft of conductors of electricity.

${ }^{2}$ In the explanation, what is meant by "circumstances" such as the occurrence of a flood or fire.

${ }^{3}$ Authority in the implementation of geothermal energy is carried out by the government and regional governments. In the utilization of geothermal energy, it is then divided into 2 (two) parts, namely exploitation for direct use and indirect use. Local governments participate in the administration of geothermal energy for direct use while for indirect use throughout Indonesia is the authority of the government.

${ }^{4}$ See Article 23 of the Geothermal Law.

${ }^{5}$ See Article 24 of the Geothermal Law

${ }^{6}$ See Article 25 of the Geothermal Law.
} 
includes the provision, exploitation and utilization of energy based on the principles of fairness, sustainability and environmental insight in order to create energy independence and national energy security. ${ }^{1}$ The national energy policy consists of the main policies and supporting policies as stated in Article 3, as followings:

1) National energy policy as referred to in Article 2 consists of the main policies and supporting policies.

2) The main policy as referred to in paragraph (1) includes:

a. Availability of energy for national needs;

b. Energy development priority;

c. Utilization of national energy resources;

d. National energy reserves.

3) Supporting policies as referred to in paragraph (1) include:

a. Energy conservation, conservation of energy resources, and energy diversification;

b. Environment and safety;

c. Prices, subsidies and energy incentives;

d. Infrastructure and access for the community to energy and the energy industry;

e. Research, development and application of energy technology; and

f. Institution and funding.

The regulation on the direction of energy policy, especially relating to the availability of energy for national needs can be seen in Article 10, as followings:

1) The availability of energy for national needs is fulfilled by:

a. Increasing exploration of proven resources, potential and / or reserves of energy, both from fossil species and new energy and renewable energy;

b. Increase the production of domestic energy and energy sources and / or from foreign sources;

c. Increasing the reliability of the production, transportation, and distribution of energy supply systems;

d. Reducing fossil energy exports in stages, especially gas and coal, and setting a time limit for starting exports;

e. Realizing a balance between the rate of adding fossil energy reserves with the maximum production rate;

f. Ensuring guaranteed environmental carrying capacity to ensure the availability of geothermal energy and water sources.

2) In realizing the availability of energy for national needs as referred to in paragraph (1), if there is overlapping of land use in the supply of energy, it is prioritized that the value of national security and / or strategic value is higher.

The state in carrying out its regulating function makes the law or other legislation an instrument for fulfilling domestic energy needs. This regulation should be able to answer the energy needs of the people. The need for energy which is increasingly increasing along with the high level of national development activities in the economic and social fields of society must be answered with the right and directed policies so that energy management can bring about a sustainable condition of energy availability. The regulation are intended so that the state cq. the government has a clear direction from the policies set. So that the management of energy resources can be projected as fulfilling energy. It is not only for current needs but also long-term needs as a condition of solid national security and achievement of people's welfare.

The potential of nature as one of energy resources is natural wealth as mandated in the constitution in order to benefit the greatest prosperity of the people. Increasing exploration activities towards potential energy resources is a strategic step to ensure the availability of energy reserves ${ }^{2}$ so that productivity can be measured in the amount of energy production. Increasing energy production is absolute to answer the increasing energy needs of the people. Besides that, reducing energy export activities needs serious attention because increasing energy production from the use of energy resources is not effective if it is not supported by a policy to stop energy exports. For the sake of maintaining energy buffer reserves which is the basis for the supply of energy, ${ }^{3}$ the energy export policy must be evaluated along with the depletion of fossil energy reserves which until now are still in the main utilization. This can be seen from the amount of energy mix where coal utilization for electricity generation in 2018 is still very high at $59 \%$, while for renewable energy only at $12 \%$.

Energy as an export commodity should be stopped based on the paradigm of utilizing energy resources as national development capital. This is important to: a) realize energy management independence; b) guarantee the availability of energy energy and fulfillment of domestic energy source needs; c) optimize the management of energy resources in an integrated and sustainable manner; d) increase the efficiency of energy utilization; e)

\footnotetext{
${ }^{1}$ See Article 2 PP No. 79 of 2014.

${ }^{2}$ Energy reserves are energy resources that have known location, quantity and quality. See Article 1 point 22 PP No. 79 of 2014.

${ }^{3}$ Energy Buffer Reserves are the amount of available energy and energy and energy sources that are stored nationally that are needed to meet national energy needs in a certain period of time. See Article 1 point 24 PP No. 79 of 2014.
} 
guarantee fair and equitable access to energy, development of technological capabilities, energy industries and domestic energy services; and f) create employment and controlling the effects of climate change and maintaining environmental functions. ${ }^{1}$

\section{OPTIMALISASI BAURAN ENERGI PRIMER}

\section{PEMBANGKIT LISTRIK}

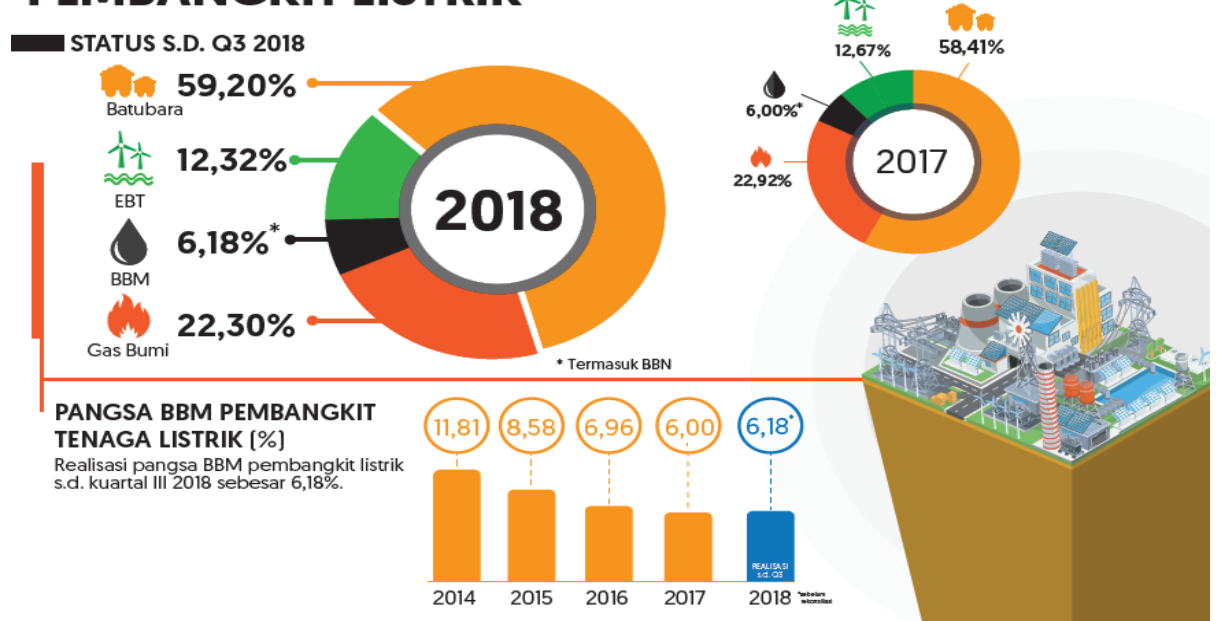

Source: DEN

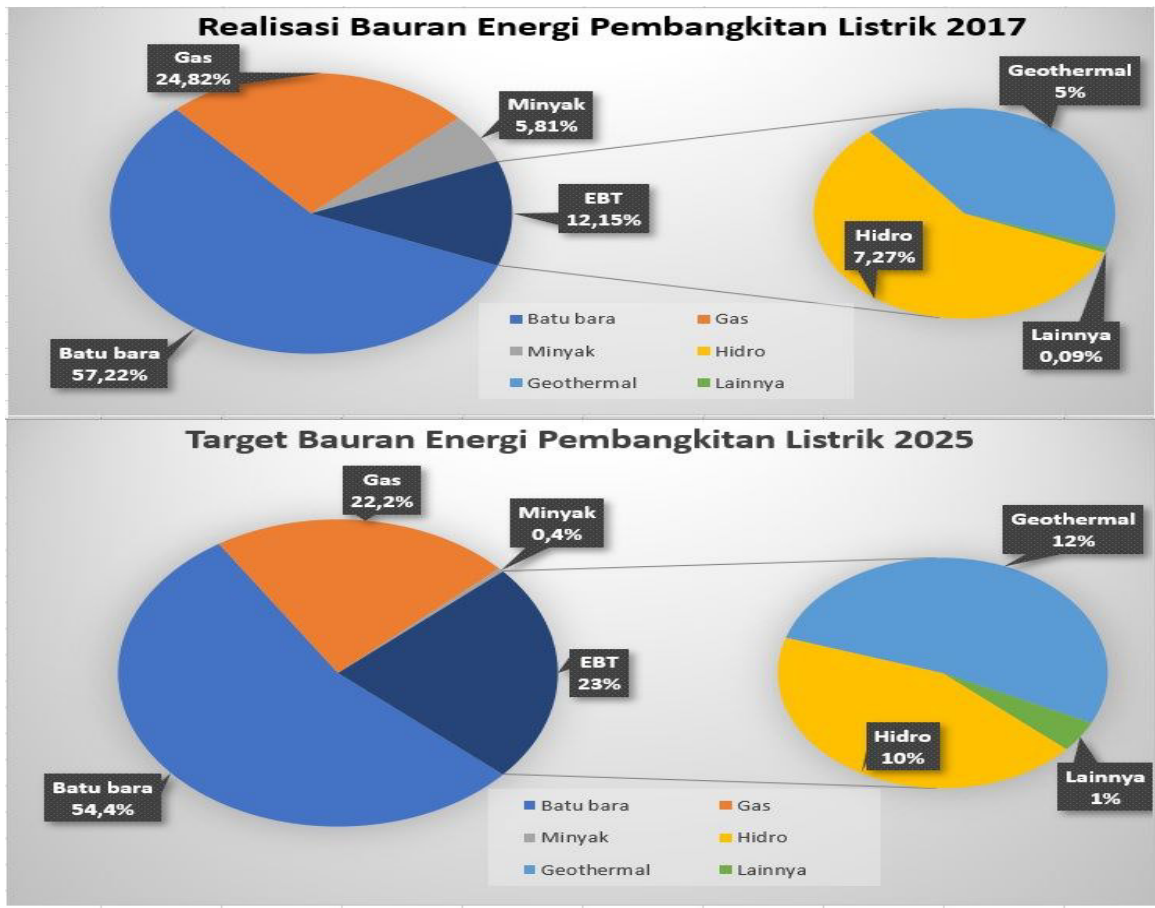

Source: Ministry of Energy and Mineral Resources

The negative impact can disrupt domestic energy supply. It will happen when Indonesia experiences dependence on energy imports. This is confirmed by the Technology Regulatory and Implementation Agency (BPPT), which estimates that Indonesia will import total energy by 2027 . This estimate will even bring Indonesia to an energy crisis if prevention efforts are not made in the form of changes in energy consumption patterns and cessation of energy export activities. ${ }^{2}$ Termination of energy exports, especially coal, which is very much needed for electricity generation, is a strategic step that requires government courage because energy management for electricity generation must be in the corridor of achieving energy mix targets.

\section{e. The Government Regulation Number 7 of 2017 concerning Geothermal For Indirect Use}

\footnotetext{
${ }^{1}$ See the explanation of the National Energy General Plan.

${ }^{2}$ See http://www.beritasatu.com/sains/376387-indonesia-dipiksi-jadi-negara-importir-energi-di-2027.html access on November 2, 2018
} 
The regulation of geothermal utilization as a source of energy today is considered very important. In addition to the large geothermal potential is around $40 \%$ of the world's geothermal potential. As an alternative energy source, geothermal becomes a potential especially to produce electricity. The regulation of geothermal energy for indirect use is a form of state responsibility in meeting domestic electricity needs. As is known that electricity is a basic need for people in carrying out development activities.

The Government Regulation Number 7 of 2017 (PP No. 7 of 2017) is mandated by Law No. 21 of 2014 concerning Geothermal as contained in the provisions of Article 17 paragraph (5), Article 18 paragraph (2), Article 19 paragraph (2), Article 22 paragraph (2), Article 39, Article 40 paragraph (3), Article 52 paragraph (2), Article 56 paragraph (3), Article 58, and Article 64. Geothermal business is an alternative step to fulfill people's electricity needs that are prospective. PP No. 7 of 2017 becomes a regulation for entrepreneurs / business entities to manage geothermal energy for indirect use as electricity generation. The provisions contained in PP No.7 of 2017 concerning the fulfillment of domestic electricity needs are technical regulation regarding geothermal exploitation for indirect use. Related to the issue of authority in the implementation of geothermal energy for indirect use is in the hands of the central government which is implemented and / or coordinated by the minister. ${ }^{1}$ The authority is regulated in Article 3, namely:

1) The authority of the central government in the implementation of geothermal energy for indirect utilization as referred to in Article 2 includes:

a. National policy making;

b. Arrangements in geothermal fields;

c. Giving IPB;

d. Guidance and supervision

e. Management of geological data and information as well as geothermal potential;

f. Inventory and preparation of the balance sheet of geothermal resources and reserves;

g. Implementation of exploration, exploitation and / or utilization of geothermal energy; and

h. Promoting research activities, human resource development, technology development and geothermal engineering capabilities.

2) The making of a national policy as referred to in paragraph (1) letter (a ) is at least in the form of:

a. Making and stipulating standardization;

b. Determination of geothermal utilization and conservation policies;

c. Establishment of cooperation and partnership policies;

d. Determination of Work Area

e. Formulation and determination of fixed contribution rates and production contributions;

f. Formulation and pricing of geothermal energy; and

g. Determination of policy.

The technical implementation of indirect use of geothermal energy is regulated in this PP relating to the determination of geothermal working areas and permits for management starting from survey activities, exploration to exploitation activities. In determining the work area, a transparent and participatory plan is needed. Transparent referred to is in case the planning process is carried out openly and is not confidential. Participatory is involving all relevant agencies in planning. ${ }^{2}$ With such planning, activities for indirect utilization of geothermal energy can provide maximum results and can minimize negative impacts in the form of both exploratory failures and widespread impacts of environmental damage.

\subsection{Responsibilities of the State as an Entrepreneur}

The presence of the state in conducting business activities through state business entities is the elaboration of Article 33 paragraph (2) of the 1945 Constitution of the Republic of Indonesia. Some branches of production are important to the state and which control the lives of many people are controlled by the state. This assertion can be interpreted that there are fundamental things that make the state have to deal directly with in the form of exploitation. This fundamental nature is the reason why private companies are not permitted to conduct business in an absolute manner because the guarantee that the important branches of production and control the livelihood of many people can benefit the greatest prosperity of the people. it becomes the responsibility of the state.

The presence or establishment of state enterprises or state-owned enterprises (SOEs) in each country is of course different. The background of its establishment is generally not only based on mere ideological reasons, but also for economic, social, political reasons, even because of historical heritage. As with the establishment of SOEs in Indonesia, historically it was inseparable from the inheritance factor of the Dutch East Indies government through a nationalization program and subsequently developed based on economic reasons in accordance with the conditions in which the state needed financial resources to develop so that the SOEs

\footnotetext{
${ }^{1}$ See Article 2 PP No. 7 of 2017 concerning Geothermal For Indirect Use.

${ }^{2}$ See the explanation of Article 6 paragraph (2) PP No. 7 of 2017.
} 
functioned as an " agent of development." ${ }^{1}$ In this connection, Mar'ie Muhammad and Astar, as quoted by Aminuddin Ilmar argues that for developing countries the presence and role of state enterprises is an essential need to accelerate national development. ${ }^{2}$

Provisions stated that he state acts as an entrepreneur in the 1945 Constitution of the Republic of Indonesia, is placed in the Chapter of the National Economy and Social Welfare (Chapter XIV) Article 33 which contains:

1) The economy is structured as a joint venture based on the principle of kinship;

2) Production branches that are important to the state and which control the livelihood of many people are controlled by the state;

3) The earth and water and natural resources contained therein are controlled by the state and used for the greatest prosperity of the people.

4) The national economy is organized based on economic democracy with the principle of togetherness, efficiency with justice, agility, environmental insight, independence, and by maintaining a balance of progress and unity of the national economy;

5) further provisions regarding the implementation of this article are regulated in law. ${ }^{3}$

The three verses (1 to 3 ) in Article 33 are the inheritance of the founding leaders remain unchanged. It can be interpreted that the economic ideology or understanding of economic democracy held by the founding fathers continues to be used as additions for the purpose of continuously improving public welfare as aspired to in the 4th paragraph of the Preamble of the 1945 Constitution. ${ }^{4}$ The provisions in Article 33 are not separate provisions as regulation for the economy and welfare. The nature of the functions of state entrepreneurs is related to the position of the state as an entrepreneur. It is a form of state responsibility in developing the economy by using the potential of natural resources which is expected to create prosperity for the people. State involvement in business activities in order to ensure that natural wealth can be enjoyed by the people through fair distribution. SOEs is a form of state control as well as an instrument for the state in managing natural resources and is used for the greatest prosperity of the people.

The ratification of article 33 as a result of this amendment is not without criticism. As one of the demands of reform, changes in the articles of the economy and social welfare are one of the agendas under discussion by the Ad Hoc (PAH) I Committee of the Workers' Body (BP) of the People's Consultative Assembly (MPR). An assessment of the existence of the article is related to the principle or principle of family. In modern business, there is no longer a system of private ownership that can be avoided as a human right that is also protected by the constitution. The principle of kinship is only relevant to the establishment of cooperatives, while in the forms of other businesses such as the company, which in effect is the principle of "one share one vote" with the award of a very high against property rights (property) that is the same height with respect to freedom ( freedom ). ${ }^{5}$

Another view regarding the branches of production that are important for the state and which control the livelihoods of many people is related to the efficiency of state-owned enterprises where it is said that the modern economy requires high efficiency. In reality, inefficiencies occur in the management of economic resources which are actually detrimental to the state. Critics of this article are also aimed at state functions that must be separated between the functions of regulation and the functions of policy makers and the functions of business actors. This view actually sees the state cq. The government is only present as a policy maker and should not be involved in business activities. State-owned companies must be privatized in order to be more efficient and ensure fairness among fellow business actors. ${ }^{6}$

The principle of economic democracy contained in Article 33 of the 1945 Constitution of the Republic of Indonesia is a reference for the presence of SOEs as representatives of the state in carrying out the functions of entrepreneurs. This is as confirmed in the basis consideration in the Law Number 19 of 2003 concerning StateOwned Enterprises (SOEs Law). In its consideration, it is emphasized that SOEs are one of the economic activity actors in the national economy based on economic democracy. The role of SOEs is very important in the implementation of the national economy in order to realize public welfare. In carrying out its role as an economic business actor in addition to other business actors, namely the private sector and cooperatives, SOEs undertake exploitation of natural resources that must be controlled by the state in order to be used for the greatest prosperity of the people.

The style of economic democracy is the basic principle of the presence of SOEs has implications for the direction and purpose of the BUMN itself. According to Jones, as quoted by Aminuddin Ilmar, ${ }^{7}$ SOEs have two dimensions, namely the public dimension and the dimensions of the business entity. Dimensions of public and

\footnotetext{
${ }^{1}$ Aminuddin Ilmar, op.cit., p. 73.

2 Ibid.p. 74

${ }^{3}$ Article 33 of the 1945 Constitution of the Republic of Indonesia NRI is the result of the fourth amendment which previously contained 3 verses into 5 verses with the title of the previous chapter which was social welfare into the national economy and social welfare.

${ }^{4}$ Jimly Asshiddiqie, Economic Constitution, $2^{\text {nd }}$ ed. Jakarta: Kompas, 2016. p. 263.

${ }^{5}$ Ibid. pp. 244-245.

${ }^{6}$ Ibid.p. 246.

${ }^{7}$ Aminuddin Ilmar, op.cit., p. 80.
} 
business entities will be determined from the possession (ownership ) as well as the supervision of the state, namely the extent of internal decisions can be made by the leader of the company. This is also stated in the Tangier meeting which explained the public dimension of SOEs is 1) goals that are community-oriented or public purpose; 2) ownership by the state or public ownership; and 3) public (public control) supervision.

The two dimensions carried out by these SOEs are often debated on the grounds that uniting the two different and contradictory dimensions cannot provide maximum results. Responding to the debate, Aminuddin Ilmar states that it is inappropriate because indeed the presence of SOEs should not be equated with private or cooperative bodies. According to Aminuddin Ilmar, the setting up of SOEs is not merely functioned as an economic unit of the state, but also functions as an organizer of production branches which are important for the state and which control the livelihoods of many people by prioritizing the elements of service and public benefit, in the form of goods, and quality and adequate services and implementing and supporting the policies of government programs in the field of economy and development in general. ${ }^{1}$

\subsection{Responsibilities of State as an Umpire}

The function of state umpire is closer to the term in which the state is in the position as a referee. As a referee, the state guarantees that all policies and actions of the state have been based on the legal rules that they make. If as a referee, then the domain is supervised or supervised. The question that can arise is how can the country become a referee who oversees himself? These questions can only be answered if the state is then divided into several parts that exercise authority. This means that there are organs that carry out the policy and there are organs that conduct supervision of other organs. This is more concretely answered by referring to the theory of trias politics where the state is divided into three branches of power. State power is translated into three branches of power, namely the executive, legislative and judicial branches. Generally, the function of the referee is carried out by the legislature as the power to form and oversee the implementation of the law. Supervision can also mean the way the state controls policy so that it can run according to the legal regulations made.

The state through the House of Representatives (DPR) holds the power to form laws. ${ }^{2}$ In addition, the DPR as stipulated in the 1945 Constitution of the Republic of Indonesia has legislative functions, budget functions and supervisory functions. ${ }^{3}$ The supervision term in Dutch is ' controle ' which means examination. The controlling function has 2 (two) equivalents, namely supervision and control. Supervision is supervision in a narrow sense as everything or activity to know and assess the actual reality about the implementation of tasks or work that is more ornately understood "from supervision, namely as any effort or activity to know, and assess the actual reality regarding the implementation of tasks or activity, is it appropriate or not. ${ }^{4}$

Prajudi Atmosudirdjo means supervision as a process of activities that compares what is carried out, done, and organized with what is desired, planned or ordered. ${ }^{5}$ Supervision is one of the elements in management activities. Supervision is an important part that can be organized independently or as a separate part. With supervision, various activities that have been outlined in the laws and regulations can be implemented properly in the sense that they are intended. ${ }^{6}$ According to Leonard White, supervision is intended to ensure that power is used for governed purposes and has the support and approval of the people, in addition to protecting human rights guaranteed by law rather than acts of abuse. ${ }^{7}$ Another view of the supervisory objectives is stated by Arifin Abdul Rachman that supervision aims to find out whether everything that runs in accordance with a predetermined plan, to find out whether everything works in accordance with instruction instructions and established principles, to find out whether weaknesses and difficulties and other failures, so that repairs can be made to correct and prevent repetition of wrong activities to find out if everything goes smoothly, and if there are more improvements, so that the efficiency greater than. ${ }^{8}$

In the administration of government, Marbun states that the meaning and function of supervision as follows: ${ }^{9}$

1.Preventing the emergence of all forms of deviated government duties and acting or correcting irregularities.

2. Supervision functions to give influence in building to shape the society to be achieved in accordance with the objectives of the state (directive), fostering national unity (integrative), caretaker and guardian of harmony, harmony and balance in the life of nation and state (stabilities) and improvement of actions - actions of state administration and safeguarding the actions of citizens in the 
life of the state and community (perspective), efforts made to obtain justice (corrective).

Likewise, when the DPR carries out the state oversight function on national energy policies, it is certainly based on the goal that energy management can fulfill the constitutional demands so that energy sources as part of national natural wealth can be used for the greatest prosperity of the people. National energy policy as an integral part of the policy of fulfilling domestic electricity needs in principle is inseparable from fulfilling electricity as a basic need of the people by which it can encourage the economic sector and realize the ideals of prosperity. Because electricity as a basic necessity of the people, related to the livelihoods of the people, the DPR as the people's representative to supervise in the form of national energy policy determination by the government must be with the approval of the DPR. This is regulated in Article 11 paragraph (2) of Law No. 30 of 2007 concerning Energy.

Article 11 paragraph (2) Law No. 30 of 2007 concerning Energy, the government with the approval of the DPR has established a National Energy Policy through Government Regulation Number 79 of 2014 concerning National Energy Policy. The meaning of the agreement is more to the element of state supervision so that the national energy policy is truly in order to meet the needs of the energy community. With the necessity of the DPR's approval, the energy policy can be controlled by ensuring that the stipulation of the energy policy is in accordance with the outline of Article 33 paragraph 3 of the 1945 Constitution of the Republic of Indonesia, energy policy which leads to the achievement of people's prosperity. In this case, Jimly Asshiddiqie ${ }^{1}$ put forward $^{2}$ in detail the oversight carried out by the legislative body including Supervision of: control of policy making, control of policy executing, control of budgeting, control of budget implementation, control of government performances, control of political appointment officials.

The other side of the involvement of the DPR as a people's representative in setting energy policies by the government, of course, is also based on the current energy situation where in general explanation PP No. 79 of 2014 concerning National Energy Policy, it places energy as a basic need that has an important and strategic role to achieve social, economic and environmental goals in sustainable national development. As population increases, it also requires economic development so that energy management must be carried out as well as possible so that it can guarantee the fulfillment of domestic energy supply not only for now but also for the future.

National energy policy is a reference in preparing national energy plans and national electricity energy plans. In its implementation, it was supervised by the National Energy Council. This is confirmed in the provisions of Article 28 PP No. 79 of 2014 as stated that the National Energy Council supervises the implementation of national energy policies that are cross-sectoral in nature.The National Energy Council (DEN) as a body that is one of the tasks of supervising the implementation of energy policies, supervisory functions are carried out by directly listening to the parties related to the government through the relevant ministries, as well as stakeholders. In the meeting DEN as the executor of the supervisory function besides pushing for the acceleration of the development of energy, for example, one of them is the acceleration of the electricity development program with its constraints ${ }^{2}$ and encouraging the development of industrial sector energy conservation. ${ }^{3}$

Supervision can also come from the government. For the utilization of energy, not only the government carries out management business activities, but also other parties in this case the private sector. Supervision is carried out in order to ensure that management activities can be in accordance with the policies outlined and based on existing legal regulations. In the Energy Law, for example, regulation for supervision are contained in Article 28, as stated that supervision of activities for managing energy resources, energy and energy sources is carried out by the government, regional government, and society.

Supervision by the government and regional government is certainly in order to ensure that all laws, policies and standard procedures established based on their authority as the government and regional governments in the field of energy can be implemented. In addition, supervision also involves the community because it is the community that is the estuary of energy management. Both the process and the output of management. In the Electricity Law, there is a division of authority in guidance and supervision between the government and the regional government. The authority is based on the principle of regional autonomy as a principle in carrying out electricity management. Supervision in this law is more on the authority of the government and regional governments to encourage the provision of electricity by maintaining adequate supply. The licensing aspect also does not escape supervision because to provide sufficient electricity supply, certain generation cannot be separated from the existence of the environment which must be maintained. Licensing is a supervisory instrument in controlling so that every electricity exploitation does not become a reason for

\footnotetext{
${ }^{1}$ Jimly Asshiddiqie. Principles of Post-Reformation Indonesian Constitutional Law. Jakarta: PT. Buana Ilmu Populer, 2007 , p.163. https://den.go.id/index.php/dinamispage/index/662-to-take-monitoring-implementation-acceleration-development-infrastructureinfrastructure-electricity -region.html accessed on October 23, 2018

3 https://www.den.go.id/index.php/dinamispage/index/614-den--rapat-koordination-pengawasan-pelimplement-keb Policy- konservasienergi- sektor- industri.html accessed on October 23, 2018
} 
environmental damage.

\section{Conclusion}

State responsibility on domestic energy needs can be seen in the state function as a provider, a regulator, an entrepreneur, and an umpire. This mandates of the Article 33 of the 1945 Indonesian Constitution to provide energy as the basic needs of the people to be used in order to reach the prosperity of the people. However, the responsibilities of the states have not been effective yet in which the domestic energy needs tend to be done in short term and they can be a threat of resilience of domestic energy.

\section{Bibliography}

Books/Journals

Abrar Saleng, Mining Law, Jogyakarta, UII Press, 2007.

Aminuddin Ilmar, The Right of State to Control in Privatization of the State-Owned Enterprises, Jakarta: Kencana, 2012.

Elli Ruslina. "The meaning of Article 33 of the 1945 Constitution in the Development of Indonesian Economic Law", Journal of the Constitution, Volume 9, Number 1, March 2012. : 68.

Farida Patittingi, Legal Dimensions of Small Islands in Indonesia. Yogyakarta: Rangkang Education. 2012.

FX. Joko Priyono. Summary the State and the Rule of Law in A Mixed Economy, in W. Friedman, Semarang: Faculty. Law of Diponegoro University, 2002.

Hans Kelsen, Introduction to Legal Theory. Translator, Siwi Purwandari. Print VIII. Bandung: Nusamedia. 2015. I Dewa Gde Atmadja, Ilmu Negara, Malang: Setara Press. 2012.

Jazim Hamidi and Mustafa Lutfi. Civic Education. Jakarta: Gramedia Pustaka. 2010.

Jimly Asshiddiqie. Economic Constitution. $2^{\text {nd }}$ ed., Jakarta: Kompas Media Nusantara. 2016. p. 216.

----------, Economic Constitution, $2^{\text {nd }}$ ed. Jakarta: Kompas, 2016.

----------, Idea of a Social Constitution. $2^{\text {nd }}$ ed.,. Jakarta: LP3ES. 2015.

----------, Constitutional Law \& Pillars of Democracy. $3^{\text {rd }}$ ed., Jakarta: Sinar Grafika. 2015.

-----------, Constitution of the State, Malang: Setara Press, 2015.

-----------, Indonesian Constitution \& Constitutionalism. $3^{\text {rd }}$ ed., Jakarta: Sinar Grafika. 2014. 2007.

Juajir Sumardi, Academic Movement for Indonesian Oil and Gas Sovereignty, Makassar: Arus Timur, 2017,.

Luthfi J. Kurniawan and Mustafa Luthfi, Regarding State, Law \& Public Policy, Malang: Setara Press, 2012.

Mac Iver, Modern Country, translated by Moertono. $2^{\text {nd }}$ ed., Jakarta: Aksara Baru, 1988.

Marbun, SF., Dimensions of Thought of Administrative Law. Yogyakarta: UII Press. 2001.

Nukthoh Arfawie Kurde. Critical Analysis of the Law State Theory . $1^{\text {st }}$ ed.. Yogyakarta: Pustaka Pelajar. 2005

Prajudi Atmosudirdjo. Administrative Law, Jakarta: Ghalia. 1983.

Ridwan HR. State Administrative Law, Revised Edition. Jakarta: Rajawali Press. 2011.

Sujamto, Some Definitions in the field of Supervision., Jakarta: Ghalia Indonesia. 1986.

Suriansyah Murhaini. Regional Government Supervision Management. Yogyakarta: Pustaka Pelajar.

Syaiful Bakhri. Oil and gas for the People, Grafindo. Jakarta: Grafindo, 2013. 45.

Victor M. Situmorang and Jusuf Juhir, Legal Aspects of Supervision Supervising. Jakarta: PT. Rineka Cipta. 1994.

\section{Websites}

http://engineering08.blogspot.com/2015/06/sejarah-adanya-listrik-di-indonesia_87.html accessed August 24, 2018.

https:/den.go.id/index.php/dinamispage/index/662-to-take-monitoring-implementation-accelerationdevelopment-infrastructure-infrastructure-electricity -region.html accessed on October 23, 2018.

https://www.den.go.id/index.php/dinamispage/index/614-den--rapat-koordination-pengawasan-pelimplementkeb Policy- konservasi- energi- sektor- industri.html accessed on October 23, 2018.

Purnawan Basundoro. http: // basundoro. blog .unair.ac.id / 2009/01/31 / from-electricity-colonial-to-listriknational-studi-awal-tentang-nv-aniem-surabaya / accessed on August 24, 2018. 